\title{
Marketing for the Project: \\ Project Marketing by the Contractor
}

\section{Introduction}

There has been an ongoing discussion in the project marketing literature about whether project management is part of project marketing or project marketing is part of project management, (Cova \& Salle, 2005). The view that project management is part of project marketing is the marketing perspective. It sets projects in the wider context of the project business and project portfolio, (Cova, Ghauri \& Salle, 2002; Tikkanen, Kujala \& Artto, 2003; Blomquist \& Wilson, 2007). On the other hand, project managers identify project marketing as a project management task, primarily stakeholder engagement, (Turner, Huemann, Anbari \& Bredillet, 2010). Turner \& Lecoeuvre (2017) have moved beyond this discussion, by taking an organizational project management perspective of project marketing, (Aubry, Sicotte, Drouin, Vidot-Delerue, \& Besner, 2012). Project marketing is an activity undertaken by organizations involved in managing projects, whereby they establish networks, processes and dialogues with their clients to provide offerings of value to their clients, (Vargo \& Lusch, 2004). Turner \& Lecoeuvre (2017) suggest that there are three types of organization involved in the marketing of projects:

1. The project itself: The project needs to market itself to its stakeholders, to engage with them and win their support. The project must convince the stakeholders the benefit they will receive from the project is greater than the value they place on the contribution they make. This is project marketing, as stakeholder management, being part of project management. 
2. The investor: The investor needs to market the investment made by the project to a wide range of stakeholders throughout the project and investment life-cycle. It needs to win the support of the owner, financiers, suppliers, politicians and local community in the early stages, and to engage with potential contractors and suppliers during the design stages. During commissioning it must sell the project's deliverables and the products or service they produce to the operators of the deliverables and the consumers of the products or services. Finally it should continue to market the investment during initial operation, to win support for future projects.

3. The contractor: Finally, the contractor needs to undertake project marketing to win new business. It has competencies the client (investor) does not have, and provides those to the client to enable it to undertake its projects. The contractor should aim to create networks, processes and dialogues with the client, to convince the client they can provide it with services that add value. The contractor also must address the adverse selection problem, and demonstrate to the client that it can be trusted to provide the competence and trustworthiness that makes it an organization the client wants to work with. This, from the perspective of the earlier discussion, is project management being part of project marketing. However, Turner \& Lecoeuvre (2017) suggest that both are part of project portfolio management, though project marketing precedes the contractor's involvement in the project and continues after it has finished.

As part of a larger research project, we are conducting empirical research into project marketing by these three types of organization exploring the three perspectives of project marketing. However, in this paper we focus on the results of our research into marketing by the contractor to win new business. The research makes use of Activity Theory as a lens to interpret the practices adopted by contractors in project-based industries to do project 
marketing, and identify how the marketing activity is shared between different managers. Our research questions for this paper are:

RQ1: What project marketing practices are adopted by contracting companies in project-based industries to find and win new business and to persuade their clients that they have the competence and trustworthiness to undertake their projects on their behalf?

RQ2: What practices are adopted by contracting companies in project-based industries to create conversations and dialogues with their clients to persuade the clients that they can make product offerings that will provide the client with value? RQ3: Who is responsible for the project marketing activity, at what stage are they engaged, and who is their target audience?

By practices, we mean the activities people undertake within project contract organizations to do project marketing. Johnson, Melin \& Whittington (2003) say, “Activities ... are the day to day stuff of management. It is what managers do and what they manage," (p15), and, "The activity based view addresses the detailed processes and practices which constitute the detailed activities of organizational life, and which relate to strategic outcomes," (p3). Jarzabkowski (2005) differentiates between practice, practices and practitioners. In this paper we are primarily focusing on the practices and practitioners, that is we wish to identify the activities, practitioners undertake to do project marketing, and who the practitioners are.

In the next section we review the literature on project marketing by the contractor, and develop models which form the basis of our research. We then describe the methodology adopted. We have conducted interviews in eight contracting companies in project-based 
industries, and used Activity Theory as a lens to analyse our results. We have used a constructivist paradigm, doing inductive research. The new theory that emerges from our data is the practices adopted by contracting organizations to do project marketing. We describe our results in two parts. From our literature review we have identified four phases of project contract management, pre-receipt of tender, tender preparation, delivery and post completion, and use Activity Theory to identify project marketing practices adopted at each stage. We have also identified the importance of collaboration and have identified four components: relationships; communication; going with; and trust. It is through these four components contractors create conversations and dialogues with the clients. We use Activity Theory to identify how those four components are built as part of project marketing.

\section{Literature Review}

Cova et al (2002) suggested project management is part of project marketing. By that they meant that project marketing results in projects. Turner \& Lecoeuvre (2017) suggest project management is not part of project marketing, but both are part of project portfolio management. Through project marketing, the contractor aims to secure a stream of projects into the portfolio. Project marketing is not about the marketing of projects, as the project marketing literature suggests, but the ability of agents to promote competencies that the contractor has that can provide value to the customer. The initiator of the project usually does not have the competencies to do the work themselves, and so they engage contractors to do it for them. The contractor aims to collaborate with the client to provide their competencies as a service to the client to create value for both. Those competencies will be provided through a project, but the focus of the marketing should be the competencies, the value that they provide the customer, and the confidence the client can have in working with the contractor. 
Project marketing researchers (Cova \& Hoskins, 1997; Cova et al, 2002; Tikkanen et al, 2003; Skaates, 2003; Lecoeuvre \& Deshayes, 2006; and Blomquist \& Wilson, 2007) have viewed a project from the marketing perspective, suggesting it is a complex transaction covering a package of products, services and works, designed to create capital assets that produce benefits for a buyer (Cova \& Salle, 2005). They go beyond project management, and broaden their perspective to the management of projects, (Morris, 1997); project marketing starts in the very early pre-project phase and continues into the post-project phase. Indeed, project management is often defined as the management of a single project from initiation to closure, whereas the management of projects is the totality of an organization's project-based activity, and includes pre- and post-project work. Cova et al (2002) focused primarily on the early stages and proposed a three-stage model for project marketing:

1. independent of any project

2. pre-tender

3. tender preparation

During the "independent of any project" phase, the contractor tries to detect emerging projects among the customers, and works with the client to try to push the definition of the project in the direction of its competencies rather than its competitors, (Bernink \& Turner, 1995). The marketing focus here is anticipation. This is followed by the pre-tender stage where project screening should take into consideration project characteristics and strategic intent, (Bernink \& Turner, 1995). Once the project has been screened and requirements reviewed, the contractor can move into the tender development phase. According to this school of thought, the first goal of the project marketing is to win the contract. 
However, project marketing is a continuous process that occurs throughout the entire management of projects process; it continues into the project delivery and follow-up phases. Follow-up, which occurs after the project has been delivered, is crucial. Lusch, Vargo \& O'Brien (2007, p7) suggest, "There is no benefit until the offering is used." and so follow-up can determine customer satisfaction, leading to key account development. Project marketing researchers (Hadjikhani, 1996; Cova \& Hoskins, 1997; Cova et al, 2002; Tikkanen et al, 2003; Skaates, 2003; Lecoeuvre \& Deshayes, 2006; Blomquist \& Wilson, 2007) consider overcoming demand-related discontinuity to be a major issue. This phase is important for identifying project opportunities and building and sustaining relationships between the buyer and the seller. This phase is very important as relationships here are maintained by social and informational exchange and affect future business (Skaates \& Tikkanen, 2002). To address the entire management of projects process, Lecoeuvre \& Deshayes (2006) proposed a fourphase project marketing process; they merged phases two and three of Cova et al (2002), and added project delivery and follow-up. Their four phases are:

1. Pre-project marketing: The project does not exist yet, but the contractor anticipates the customer's requirements, identifies themes for the potential bid (Bernink \& Turner, 1995), and develops the relationship with the client.

2. Marketing at the start of the project: The contractor starts with co-construction of terms of engagement within the network of influential relationships related to the project?

3. Ongoing Project Marketing: The contractor, client, and subcontractors proceed with renegotiation, modifications, follow-up, and meetings following one another with constant relationship exchanges until the end of the project. 
4. Creating the conditions for future projects: The contractor maintains the relationship with the client, through logistics support and "sleeping relationships" which enables it to manage discontinuity in project business and prepare for future projects.

Based on these two models, we suggest there are four stages of project marketing:

1. Pre-receipt of invitation to tender

2. Tender preparation and contract negotiation

3. Project delivery

4. Post-project

The previous researchers have identified these four stages of project marketing. But they have not identified what it is that managers do at each stage, nor which managers are involved. That leads to our first research questions, to identify the practices or activities adopted to undertake project marketing in project contract organizations.

Lecoeuvre \& Deshayes (2006) also focused on the development of collaborative relationships with clients, and suggested that there are four enablers of collaboration:

1. Relationship management

2. Communication

3. Going-with, (providing mentoring, coaching and support)

4. Trust (Tru) 
Lecoeuvre and Deshayes (2006) identified the need to develop collaborative arrangements with clients using these four elements, but again did not identify the activities or practices adopted to develop them. That is the basis of our second research questions.

Bernink \& Turner (1995) identified three key stakeholders as the target of project marketing:

The strategic decision makers: These are the people who will ultimately decide to do the project, and determine which contractor will be awarded the contract. They are interested in the project's goal. It is the contractor's executive managers who target these people.

The operations managers: These are the operators of the project's output, the project's deliverable, and the operators and consumers of its outcome, the new competencies the project's output gives the client, the operation of which enables the client to achieve value, (Turner, 2014). They are less interested in the technology, and more concerned that the project's output works as required to provide the desired outcome, (Turner, 2014). They are interested in achieving the outcome, not the technology behind it. It is usually the role of account or client management personnel to communicate with these people. It is essential to make them comfortable that the project's output and outcome will satisfy their requirements and provide them with the benefit they want.

The project and technical mangers: These are the people who will judge the contractor's technical solution and will be able to determine whether the project's output will work to provide the outcome. The contractor's project and technical managers will communicate with these people to persuade them of the contractor's technical competence.

Thus there are three levels of managers in the contractor involved in project marketing: 


\section{Executive managers \\ 2. Account or client managers \\ 3. Project and technical managers}

This leads to our research question, to identify how these three types of managers are involved in the project marketing process, to determine at what stage they are involved, and what activities they perform.

The three research questions are raised to present the complications of the research situation which resulted in the research questions that elicit the concerns being addressed in this paper about how the contractor markets their competencies and trustworthiness to win business.

\section{Methodology}

Our aim is to identify the practices used in project marketing by contractors in project-based industries, and identify who is responsible for implementing the practices. We used a constructivist paradigm, using an inductive research approach as the phenomenon we were investigating is under researched, (Alvesson \& Kärreman, 2011). The investigation made use of an interpretive methodology which according to Walsham (2002, p.104), uses an existing theory as an 'initial guide to design and data collection, use of theory as part of an iterative process of data collection and analysis, and as a final product of the research'. Activity Theory, (Er, Pollack \& Sankaran, 2013), provided that theoretical perspective through which the interviews were examined and was considered to be most appropriate as it provides a holistic framework to examine decision making as a part of the work process (Er and Lawrence, 2011). We use Engestrom's (2000) model of Activity Theory model as it is well referenced and has been previously used by researchers to analyse work practices, which suggests it is an appropriate course of action to address our research questions (Figure 1). 
Activity theory is a framework for the analysis of human interaction through their use of tools and artefacts, (Hashim \& Jones, 2007). It was originally developed to provide a framework to describe human behaviour with the unit of analysis being what people do. Activity theory is appropriate as a framework of analysis as we are trying to identify practices (activities) used as part of the project marketing process, and the practitioners who enact those activities. Under Activity Theory, a subject or actor undertakes an activity to achieve an object. The subject may be an individual or a group, depending on the granularity of examination. On the higher level (when considering the overall group as the subject) we are able to identify the overall object that motivates the focus group of people. Activity Theory allows the researcher to maintain this holistic view of the group and allow consideration of individual sub-activities. We will consider both the activities undertaken by the organization, and the managers responsible.

How well the object is achieved will determine the outcomes. Kuutti (1996) noted that the motivation (the object) of the activity is not always obvious. The actor uses tools to undertake the activity, and is subject to constraints imposed by rules, the community of practice and the division of labour. Some of the rules are explicit. They are either required, or they are guidelines from theory, or professional standards. Other rules are implicit, guided by the culture of the organization or that of the community of practice (profession).

Different people or organizations may also participate at different stages of the activity, with work divided between them. As noted above, the subject may be an individual or a group depending on the focus of the researcher, and the activity can be analysed from the perspective of the individual or group. We looked at what the companies we interviewed are 
doing, and also people holding certain job roles within the companies. Work practices of contractors is the focus of our research. Work practices, particularly implicit rules have also been described by researchers such as Suchman (1995) as black boxes, as the way people work based on tradition and sometimes cannot be readily explained by individual workers, rather 'it is just the way we do it'. Activity Theory suggests that work practices is something developed over time and through the different perspectives of individuals that make up the subject of our focus allows for unwrapping the layers of an activity, providing a platform that reveals the underlying logic behind the forces that mediate the activity.

We conducted unstructured interviews in eight organizations from the private sector, Table 1. In keeping with qualitative research traditions, we approached the research using a thematic analysis to allow the theory to emerge from the data. Nevertheless we used specific questions to initiate conversations and these included:

1. We asked the interviewees whether they recognized the concept of project marketing.

2. We asked the interviewees to consider each of the four stages of the project contract lifecycle.

3. We asked the interviewees to consider each of the four enablers of collaboration.

Interviews were conducted by two teams, one in Europe and one in Australia. Data was collected using the same questionnaire in the eight organizations. One of the authors from Australia additionally participated in on the first (pilot) interview conducted in Europe to discuss adjustments to the questionnaire that was used subsequently. Data collected from the interviews were transcribed and shared between team members. 
Three of the authors met to conduct an analysis of the interviews using an Activity Theory lens. At the workshop, a laboratory with a large screen was used to display the transcribed interview so the analysis could be done collaboratively. Each interview was displayed on the screen and Activity Theory (Figure 1) was used to discuss what emerged from the interview that illustrated the use of the elements of Figure 1 at the four stages of the contract life cycle: pre-receipt of invitation to tender (Table 2), tender preparation and contract negotiation (Table 3), project delivery (See Table 4) and post-project stage (See Table 5). This process was repeated for the four elements of collaboration: relationship; communication; going-with; and trust (the results for all four being shown in Table 6). Individual interviews were analysed (within case analysis) the common themes that arose from all the interviews (cross case analysis) were identified. The workshop lasted eight hours.

\section{Marketing throughout the Project Life-cycle}

The four stages of the project contract life-cycle were recognized by our interviewees.

\section{Pre-receipt of invitation to tender}

Key results for the pre-tender stage are shown in Table 2.

At this stage the focus of marketing is strategic. The work is shared by executive management and marketing, including client and account management. One of our interviewees said:

\footnotetext{
"At this stage we are driven by strategic intent.... We are looking to develop key markets"
} 
The main focus is to identify potential opportunities, to understand the client's true requirement and match the firm's competencies to the requirements. Understanding the client's true requirement is significant here and at the next stage. It is about understanding the benefit they want, and not just the technology they are looking for. Understanding the client's benefit 'to assist them in their own value-creation process' (Vargo \& Lursch 2008, p5) is part of the service-dominant logic of marketing, (Lusch et al, 2007; Skålén, Gummerus, von Koskull \& Magnusson, 2015). Matching the firm's competencies to the client's requirements is key in deciding whether to pursue this opportunity, but also in trying to persuade the client that the firm's competencies are superior to the competitions'.

Marketing at this stage of the life-cycle, is led executive managers who will be targeting the client's executive managers. Marketing, client or account managers will be in support, targeting the client's general managers who are buying the solution. Project and technical managers are not involved in the marketing activity at this stage.

We have shown the two enablers of collaboration as tools guiding this stage, building relationships and developing trust. This is the same as identified by Lecoeuvre \& Deshayes (2006). Relationship building is very important. One of our interviewees said:

"It is important to build relationship before receiving the tender. When the tender comes it is too late."

A significant constraint is the need for probity. This had a range of impacts. All firms have to be concerned about adhering to rules for bribery and corruption. But in the onshore oil and gas industry probity eliminated almost all direct contact with the client. The contractor could 
respond to requests for information for prequalification purposes but not have direct, one-toone meetings, such as strategy meetings, other contractors were able to have. Effectively the client's concern for probity, and not giving one contactor an unfair advantage, was limiting the contractor's ability to do project marketing and build relationships. Our interviewees in the building and defence industries had no such constraint, and engaged in strategy meetings with the client. The off-shore oil and gas industry was somewhere in between, but our interviewees said that they often suggested potential opportunities to the client.

The main elements of the community are the contractor and client. However, the contractor needs to be concerned about potential competitors and to make contact with sub-contractors and suppliers. Industry bodies may be able to provide information. At this stage as well, it is good to start to develop relationships with the local community and politicians.

\section{Tender preparation and contract negotiation}

Key results for tender preparation stage are shown in Table 3.

At this stage the focus of marketing is tactical. The executive management team become less involved, but the project management team are now involved. Some of the work may be given to sub-contractors or suppliers. Client or account management showed a particular concern about the submission of the tender, and suggested that they would have the final act before submission to "massage" the tender to increase the attractiveness to the client.

Understanding the client's budget and whether that lets the contractor make a profit are key. The significant focus continues to be understanding the client's true needs and matching the client's needs to the firm's strengths. One of our interviewees said: 
“A key initial step is to understand the customer's requirement. What benefit do they want? Don't just deliver the technology they are asking for."

Again, this fits within the framework of the service-dominant logic, (Hsieh \& Hsieh, 2015).

Setting a winning price is clearly important. Several of our interviewees indicated that it was important to be aware of the client's budget. It was also essential to balance product and price, to understand whether the client wants minimum capital cost or minimum life-cycle, cost. Offering effective project and program management also provided additional benefit to the client that would enable the firm to charge a higher price. Several of our interviewees also took significant opportunities to promote themselves through the tender exercise.

As with the previous stage, probity is a key rule. A constraint from within the contractor is the need to apply lessons learnt, and apply internal and external standards.

At this stage all four enablers of collaboration are important. Relationships and communication became more formal. In the onshore oil and gas industry it is very formal. The only contact allowed with the client is to post questions on the client's web page that all contractors can see. In the past the client would allow each contractor one meeting and then distribute minutes of the meeting to all contractors. But since only $30 \%$ of communication is in the words used, the minutes only communicate $30 \%$ of what the contractor learnt. Therefore, contact is now limited to questions posted on the client's web-page, so no contractor gains unfair advantage. The defence contractor worked hard at this stage to understand the client's true need, and that required more meetings with the client. In this industry it may be more difficult to divine the client's true need and so a closer working 
relationship may be needed. Several of our interviews also talked in terms of developing a partnership with the client, indicating the significance of collaboration. There are also several components of trust, including trust of competence and trust of ethics, (Turner, 2014). The client will be concerned about the adverse selection problem at this stage, (Turner, 2014), and so it is important for the contractor to build the client's trust in its competence and ethics, and make the client believe that the contractor is a company that the client wants to work with.

Providing local content is often an important requirement, particularly in the off-shore oil and gas industry (Merrow 2011). If it is, then it becomes significant at this stage.

\section{Project delivery}

Key results for the project delivery stage are shown in Table 4.

The focus of marketing is now operational. It becomes the responsibility of project managers. Patel (2010) found that in general project managers do not think they have much responsibility for marketing, but we found that they have significant responsibility at this stage. Most of our interviewees said that performance on the project was important for winning future business and that project managers should be looking for future opportunities. One of our interviewees said:

"Real business development is the project itself. The business development task is the ongoing project" 
Delivering the client's requirement is important. The client gets no benefit until the output works and produces the outcomes, (Lusch et al, 2007; Groonroos \& Gummerus, 2014). Effective project and program management provide the customer with value. Regular meetings with the client will take place on the project. The contractor should be looking for a win-win solution with the client, (Groonroos \& Gummerus, 2014). Our interviewees talked in terms of a partnership with the client rather than collaboration with the client. One said:

"We do with the client rather than unto the client".

The contractor looks to the post-project stage, and initiating going-with, providing mentoring, and looking ahead to providing logistics support. At this stage, adherence to standards and codes and to local laws and regulation, and to the terms of the contract is important. It is also important to maximise the use of lessons learned. Local content is also important.

\section{Post project}

Key results for the post project stage are shown in Table 5.

It is important to build and maintain trust for the next project. Lecoeuvre \& Deshayes (2006) suggested that at this stage of the project, of the four enablers, three are important: relationships, communication and trust. We specifically identified trust. The emphasis now has changed from trust in competence to trust in ethics. Going-with, that is the provision of mentoring and logistics support, will also maintain the relationship with the client.

At this stage, a common rule among our interviewees is to gather lessons learnt. A rule observed at the earlier stages was to make use of the lessons learnt. At the post-project stage 
gathering the lessons learnt was an important part of the cycle that populated the knowledge base. We observed at the earlier stages that trust of the client in the contractor's competence was important such as at the pre-tender quantification. The lessons learnt are an enabler for the contractor to improve competence and further develop trust with the client.

\section{Enablers of Collaboration}

Our interviewees all reported that they put substantial effort into building and maintaining the four enablers of collaboration. The activities identified for developing the four enablers of cooperation are shown in Table 6.

\section{Relationships}

Relationships are essential. They are to an extent what it is all about, and are a key part of the service dominant logic since that is about building networks. One of our interviewees said:

"It is all joint. ... Because we have a good relationship, we know how to deal with everybody. They all have their own peculiarities, but we know them well. ... How we maintain the relationship makes us the partner of choice"

Our interviewees emphasized the arrangement of meetings and joint events with the client. But, the need for probity limited the extent that contractors in the onshore oil and gas industry could interact directly with clients. The four enablers of collaboration are all linked.

Communication and trust are key elements of building and maintaining relationships, and relationships are a key part of going with. Training, mentoring, logistics and maintenance support are also all essential elements of building and maintaining relationships. Probity is 
an important rule for relationships. Building trusts is also an essential rule. Demonstrating ethics and adhering to the client's cultural norms are key to trust.

\section{Communication}

Communication pervades collaboration. Communication is two way; it involves listening as well as talking. Solving the client's true problem shows you are listening. Several of our interviewees emphasized the need to listen to the client and solve its true problem. Don't just provide it with the project output it is asking for, but understand its true need and provide them with the project outcome they require, which will deliver the benefit they require and thereby provide them with value. Regular contact with the client is a key part of communication, and so communication is strongly linked to relationships. It is also important that communication occur at the right level, so an escalation procedure is key.

\section{Going with}

Many of our interviewees talked in terms of developing a partnership, which goes beyond collaboration. As we have said, one of our interviews talked in terms of doing with rather than doing unto, (Akaka, Vargo, \& Lusch, 2013). Another said:

"Fit with the customer can provide a strong competitive position"

The four enablers of collaboration are all linked. Communication and relationships are part of going with, going-with builds trust, and many of the activities are repeated, such as solving the client's true problem and holding of regular meetings. It is about establishing networks, processes and dialogues with clients to provide offerings they value, (Vargo \& Lusch, 2004; 
Lusch et al, 2007; Groonroos \& Gummerus, 2014). Training, logistics and maintenance support are project management activities which are all a key part of collaboration.

\section{Trust}

There are two key elements of the client's trust of the contractor, trust in ethics and trust in competence. This is related to the adverse selection problem, (Turner, 2014). Several of our interviewees emphasized the need to make the client trust them, to make it easier for the client to select them. Probity, honesty and transparency are rules for maintaining trust in ethics. It is also related to the moral hazard problem, (Turner, 2014). The client must be confident the contractor will not behave opportunistically. Trust is also two way. The contractor must trust the client, and most of our interviewees said they would walk away from relationships where they didn't trust the client.

\section{Discussion}

We can now propose answers to our three research questions.

RQ1: What practices are adopted by contracting companies in project-based industries to find and win new business and to persuade their clients that they have the competence and trustworthiness to undertake their projects on their behalf?

We used Activity Theory to identify the practices adopted by contractors in project-based industries to market their competencies to their clients. Our interviewees recognised the four stages of the contract life-cycle suggested. The practices adopted at each stage are described in Tables 2 to 5. Contractors exist to integrate and transform their specialist competencies into services that are demanded in the market place, and which can provide their customers with value. That ability provides them with competitive advantage. Our interviewees 
suggested they are not marketing projects. They are marketing their competence, trustworthiness, and nature as an organization that clients want to work with. This is different than suggested by previous research, (Cova \& Salle, 2005), which posited that project management is part of project marketing. Our results are supportive of the ideas of Turner \& Lecoeuvre (2017) that both project marketing and project management are part of project portfolio management. The aim of project marketing is to win new business, not by marketing projects, but, as we said, by marketing the firm's competence and trustworthiness, and thereby reducing the adverse selection problem. Successful project marketing will result in new projects, but they will also be managed as part of the project portfolio.

We identified the focus of project marketing changes through the contract life-cycle. In the pre-project stage, the emphasis is strategic: identifying new business, understanding the client's true need, and matching the firm's competence to that need. It is also on developing relationships with potential customers and developing trust. In tender preparation and contract negotiation, the emphasis is tactical: it widens to selling the firm's competence to the client, and matching the price to their expected benefit. In project delivery, the emphasis is operational: on delivering the desired outcome capable of working to deliver the required outcome, and on forward selling, that is identifying new opportunities. The focus of collaboration is on maintaining the relationships. Finally, in post project, the emphasis is now on mentoring and providing logistics support, that is going-with, to maintain the relationship. It is not a sleeping relationship as Lecoeuvre \& Deshayes (2006) suggest, but an active one. There is also a focus on maintaining trust, but the focus is now on trust in ethics, that is the contract is a firm the client wants to business with, rather than trust in competence. 


\section{RQ2: What practices are adopted by contracting companies in project-based}

industries to create conversations and dialogues with their clients to persuade the clients that they can make product offerings that will provide the client with value?

We used Activity Theory to identify the practices adopted to develop collaboration with the client against the four elements: relationship management; communication; going-with; and trust, Tables 6. Our interviewees thought all four elements were significant in building and maintaining relationships with clients. In accordance with both the service dominant logic of marketing, (Vargo \& Lusch, 2004; Lusch et al, 2007; Groonroos \& Gummerus, 2014), and the concepts of organizational project management, (Aubry et al, 2012; Turner \& Lecoeuvre, 2017), contractors aimed to build networks, conversations and dialogues with customers, to develop solutions of value both to their clients and themselves. There was a changing emphasis during the contract life-cycle. Pre-invitation to tender, the emphasis was on building trust and relationships with the client. At invitation to tender and contract negotiation, the focus widened to building the channels of communication with the client. At project delivery, there is an ongoing need for communication, but implicitly the contractor also looks forward to the post project phase, and initiates going-with, that is mentoring and logistics support. During the post-project phase, the emphasis is on-going-with and trust. But the main component of trust is now trust in ethics; the contractor wants to convince the client that they are a company that will treat the client well and with respect, and that they are a company the client wants to do business with which is grounded in their experience with the contractor in the delivery phase. Common rules included the need for probity, trust, honesty and transparency. They also included the need to listen to the client and solve their true need, and to have an escalation procedure to deal with issues. 
RQ3: Who is responsible for the project marketing activity, at what stage are they engaged, and who is their target audience?

Executive managers, marketing and account managers and project and technical managers have responsibility for different elements of marketing; their focus is strategic, tactical and operational respectively, targeting appropriate managers in the client organization. Again there is changing responsibilities throughout the contract life-cycle. During the pre-invitation to tender stage, the executive managers have a strategic focus on identifying the client's true requirement by understanding their strategic need. The account/client managers are also trying to understand the client's true need and initiate the building of relationships. At tender preparation and contract negotiation the focus is tactical; the account/client managers manage the bid process, while the project and technical managers prepare the bid. During project delivery the focus is operational; project managers are responsible for delivering a project output capable of achieving the client's desired outcome. They must also be forward selling, looking for future opportunities, and making account and executive managers aware of them. During the post-project phase, all three have a responsibility. Project managers must ensure the output works to achieve the outcome, (Turner, 2014). Project managers must also gather lessons learnt, and be aware of future opportunities. Client managers focus on those issues and also look for opportunities of providing the client wit logistics and operational support. Executive managers work with the client to look for new strategic needs.

\section{Conclusions}

Four points stood out:

1. The emphasis on project marketing varies through the contract life cycle, and is the responsibility of different managers at different stages. In the pre-receipt of in the 
invitation to tender stage, the focus is strategic and marketing is the responsibility of executive managers. The main concern of collaboration is the initial building of relationships. In the tender preparation and contract negotiation stage, project marketing is tactical, and is mainly the responsibility of the account or client managers. The main concern of collaboration is establishing the channels of communication. In project deliver, the emphasis is operational, and marketing is the responsibility of project managers. The main concern for cooperation is on-going-with, establishing mentoring, coaching and support. In the post-project stage, the emphasis is strategic, tactical and operational, and all three sets of managers are involved. The main concern of collaboration is on maintaining trust for future projects, and maintaining the relationship.

2. Project managers have a responsibility for project marketing. Patel (2010) suggested they are often not aware of this. They need to understand that tender preparation is a key element of project marketing. In addition, during project delivery, they need to be aware successful delivery of this project will build trust in competence for future projects, and be aware of potential future opportunities. They also need to build relationships through post-project activities such as training, mentoring, logistics and maintenance support. Additionally, the ability to provide effective project and program management provides competitive advantage, which demonstrates competence, helps a contractor to develop relationships with various clients, win work and charge a higher price.

3. There are differences by industry, though the main difference was provided by the client's desire for probity. In the on-shore oil and gas industry there could be no one to one contact with the client during the pre-receipt of invitation to tender and tender preparation and negotiation stage. This limited the contractor's ability to build all four elements of 
collaboration in those four stages. The clients' concern was that direct contact with one contractor would give that contractor an unfair advantage. This of course is precisely what Bernink \& Turner (1995) recommended, and quoted an example of a contractor who said that if they had not been working with the client during the pre-receipt of the invitation to tender stage, their competitors will have been and it may not be worth bidding. Similar sentiments were expressed by three of our interviewees. In the off-shore oil and gas industry, there is a strong emphasis on maintaining relationships with clients between projects. There is also a strong emphasis on local content in projects, maintaining workshops to employ local labour to build modules for use off-shore. In the defence industry, there was a strong emphasis on maintaining an ongoing relationship with clients between projects to understand and guide the definition of their future requirements.

4. The service dominant logic pervades marketing by contractors in project-based industries to win new business. Contractors exist to undertake work on projects that the client (initiator) cannot do for themselves. The contractor has knowledge, competencies and skills that the client does not have internally, and can provides those services to the client to enable the client to undertake their projects, and provide it with value, delivering a project output and outcome that will provide the client with benefit, (Lusch \& Vargo, 2014). The emphasis is on building collaborative relationships, and working with the client rather than for the client, (Akaka et al, 2013). The results-based view of project management, also suggests that project success is achieving the business objectives, that is the project output works to achieve the outcome and deliver the desired benefit, (Turner, 2014). (Project management success is delivering the output to time, cost and quality, Serrador \& Turner, 2015.) Our interviews were aware of this. As Lusch et al 
(2007, p7) suggest, "There is no benefit until the offering is used.” Finally, as we have seen, developing collaborative arrangements with the client is about establishing networks, processes and dialogues with clients to provide offerings they value, (Vargo \& Lusch, 2004; Lusch et al, 2007; Groonroos \& Gummerus, 2014).

Next we present the contributions from our research in the form of academic (theory) and practical implications (practice) to project marketing.

\section{Academic implications}

We have used Activity Theory to identify practices adopted by contractors in project-based industries to market their competencies to clients to win new work. We have shownshow that the emphasis is on selling the firms competencies and skills to deliver a project output that will work to deliver benefit and thereby provide the client with value. We observe the project marketing principle to develop trust in the contractor to work with the client and to deliver a project plays an implicit and important role in winning new work. We have shown how the practices vary through the contract life-cycle, and the responsibilities of different managers at the different stages. We also identified practices adopted to develop collaboration.

\section{Practical implications}

The results provide guidelines to contractors in project-based industries who wish to improve their marketing activity to achieve sustainable performance. Industry may also find it useful to train or coach their project managers to be conscious of their marketing role. 


\section{References}

Akaka, MA, Vargo, SL \& Lusch, RF (2013) The complexity of context: a service ecosystems approach for international marketing. Journal of Marketing Research, 21(4), 1-20.

Alvesson, M, \& Kärreman, D (2011). Qualitative Research and Theory Development. Thousand Oaks, CA: Sage.

Aubry, M, Sicotte, H, Drouin, N, Delerue H, \& Besner, C (2012) Organizational project management as a function within the organization. International Journal of Managing Projects in Business. 5(2):180-194.

Bernink, B (1995) Winning contracts. In JR Turner (ed) The Commercial Project Manager London. McGraw-Hill.

Blomquist, T \& Wilson, T (2007) Project marketing in multi-project organizations: a comparison of IS/IT and engineering firms. Industrial Marketing Management. 36(2):206-218

Cova, B, Ghauri, P \& Salle, R (2002) Project marketing - beyond competitive bidding Chichester: Wiley.

Cova, B \& Hoskins, S (1997) A twin-track networking approach to project marketing. European Management Journal 15(5):546-556.

Cova, B, Mazet, F \& Salle R (1996) Milieu as a pertinent unit of analysis in project marketing, International Business Review 5(6): 647-664.

Cova, B \& Salle, R (2005) Six key points to merge project marketing into project management International Journal of Project Management 23(5):354-359.

Engestrom, Y. (2000) Activity Theory as a framework for analysing and re-designing work, Ergonomics, 43(7): 960-974. 
Er, M \& Lawrence, E. (2011) Using Activity Theory to Examine Information Systems for Supporting Mobile Work, In Proceedings of the 24 $4^{\text {th }}$ BLED eConference, 12-15 June, 2011, Bled, Slovenia.

Er, M, Pollack, J \& Sankaran, S (2013) Actor Network Theory, Activity Theory and Action Research and their application in Project Management Research. In N Drouin, R Müller \& S Sankaran (eds), Novel Approaches to Organizational Project management research: translational and transformational Copenhagen: Copenhagen Business School Press. Foreman, S (1996) Internal marketing. In JR Turner, KV Grude \& L Thurloway (eds) The Project Manager as Change Agent London: McGraw-Hill.

Graham, RG (2007) Managing conflict. In JR Turner, (ed), The Gower handbook of Project Management, $4^{\text {th }}$ edition. Aldershott: Gower.

Groonroos, C \& Gummerus, J (2014) The service revolution and its marketing implications: service logic vs service-dominant logic. Managing Service Quality. 24(3):206-229.

Hadjikhani, A (1996) Project marketing and the management of discontinuity, International Business Review 5(3): 319-336.

Hashim, NH \& Jones, ML (2007) Activity theory: a framework for qualitative analysis. In Proceedings of the 4th International Qualitative Research Convention (QRC), 3-5 September, 2007, PJ Hilton, Malaysia.

Hsieh, JK, \& Hsieh, YC (2015) Dialogic co-creation and service innovation performance in high-tech companies. Journal of Business Research. 68:2266-2271.

Jarzabkowski, P (2005) Strategy as Practice: an activity based approach. London: Sage Johnson, G, Melin, L \& Whittington, R (2003) Micro strategy and strategizing: towards and activity based view. Journal of Management Studies. 40(1), 3-22 
Keegan, AE, Turner, JR \& Huemann, M (2007) Managing human resources in the projectbased organization. In JR Turner, (ed), The Gower handbook of Project Management, $4^{\text {th }}$ edition. Aldershott: Gower.

Kotler, P \& Lane, K (2008) Marketing Management Prentice Hall.

Kuutti, K, (1996) Activity Theory as a potential framework for Human-Computer Interaction Research. In B Nardi *ed), Context and Consciousness, Cambridge: MIT Press, 17-44.

Lecoeuvre, L \& Deshayes, P (2006) From marketing to project management. Project Management Journal 37(5):103-112.

Lusch, RF, Vargo, SL \& O’Brien, M (2007) Competing through service: insights from service dominant logic, Journal of Retailing, 83(1), 5-18.

Lusch, RF \& Vargo, SL (2014) Service-dominant Logic: Premises, Perspectives and Possibilities. Cambridge: Cambridge University Press.

Merrow, EW (2011) Industrial Megaprojects: Concepts, Strategies and Practices for Success, New York: Wiley.

Patel, K (2010) Investigating the Importance of Project Marketing in Project Management, PhD Thesis, SKEMA Business School, Lille.

Serrador, P \& Turner, JR (2015) The relationship between project success and project efficiency. Project Management Journal. 46(1), 30-39,

Skaates, MA \& Tikkanen, H (2003) International project marketing: an introduction to the IN bPM approach. International Journal of Project Management. 21:503-510.

Skålén, P, Gummerus, J, von Koskull, C \& Magnusson, PR (2015) Exploring value propositions and service innovation: a service-dominant logic study. Journal of the Academy of Marketing Science. 43:137-158

Suchman, L., (1995) Making work visible. Communications of the ACM, 38(9), pp.56-64. 
Tikkanen, H, Kujala, J \& Artto, K (2007) The marketing strategy of a project-based firm: the four portfolios framework. Industrial Marketing Management 36(2):194-205.

Turner, JR (2014) The Handbook of Project-Based Management $\left(4^{\text {th }}\right.$ ed) New York: McGraw-Hill.

Turner, JR, Huemann M, Anbari FT \& Bredillet CN (2010) Perspectives on Projects. New York: Routledge.

Turner, JR \& Lecoeuvre, L (2015) Marketing the Project Portfolio. In G Levin, (ed). Portfolio Management: a strategic approach, Boca Raton, FL: CRC Press.

Turner, JR \& Lecoeuvre, L. (2017). Marketing by, for and of the project: project marketing by three types of organization. International Journal of Managing Projects in Business, $10(4), 841-855$.

Vargo, SL \& Lusch, RF (2004) Evolving to a new dominant logic for marketing, Journal of Marketing, 68, 1-17

Vargo, SL \& Lusch, RF (2008) From goods to service (s); divergences and convergences of logics, Industrial Marketing Management, 37(3): 254:259.

Walshham, G. (2002) Interpretive case studies in IS research: nature and method, in M. Myers \& D. Avison (eds,) Qualitative research in information systems. London: Sage Publications, 